\title{
Characteristics of technology transfer in business ventures: the case of Daejeon, Korea
}

\author{
Tae Kyung Sung ${ }^{\mathrm{a}, *, 1}$, David V. Gibson ${ }^{\mathrm{b}, 2}$, Byung-Su Kang ${ }^{\mathrm{c}, 3}$ \\ ${ }^{a}$ College of Business, Kyonggi University, 94-6 Yiui-Dong, Paldal-Gu, Suwon 442-760, Republic of Korea \\ ${ }^{\mathrm{b}} \mathrm{IC}^{2}$ Institute, University of Texas at Austin, 2815 San Gabriel, Austin, TX 78705, USA \\ ${ }^{\mathrm{c}}$ Department of Local Government Administration, Chungnam National University, Daejeon, Republic of Korea
}

Received 7 August 2001; received in revised form 20 June 2002; accepted 11 September 2002

\begin{abstract}
This article explores the characteristics of venture business and entrepreneurs in Korea to (1) identify technology transfer activities, (2) analyze the differences between technology transfer in linear and nonlinear venture businesses, and (3) guide more effective venture business policy and strategy. This empirical assessment reveals that entrepreneurs have insightful evaluations about their resources and capacities as well as expectations with regard to functions and features of science parks and incubators. Respondents from "linear model"-based start-ups tend to be older and have higher education, employ more basic research and development (R\&D) and have more R\&D-oriented careers, and have more varied work experience than "nonlinear"-based start-ups. The functions and features of science parks and incubators were generally not considered a critical influence on start-ups nor on the growth of venture businesses. Accordingly, alternative venture-nurturing strategies are discussed as being key to accelerate venture businesses growth.
\end{abstract}

(C) 2002 Elsevier Science Inc. All rights reserved.

Keywords: Technology transfer; Daejeon, Korea; Linear and nonlinear venture businesses

* Corresponding author. Tel.: +82-31-249-9457; fax: +82-31-249-9401.

E-mail addresses: tksung@kuic.kyonggi.ac.kr (T.K. Sung), davidg@icc.utexas.edu (D.V. Gibson), kbs@cnu.ac.kr (B.-S. Kang).

${ }^{1}$ Tae Kyung Sung is a professor in the Department of MIS of Kyonggi University, South Korea.

${ }^{2}$ David V. Gibson is a research fellow at the IC ${ }^{2}$ Institute of the University of Texas at Austin, Austin, TX, USA.

${ }^{3}$ Byung-Su Kang is a professor in the Department of Local Government of Administration, Chungnam National University, South Korea. 


\section{Introduction}

As we move into the 21st century, knowledge-intensive, high-technology industries are expected to be the most critical and strategic industries for the survival and the growth of companies, regions, and nations [1]. This expectation, together with rapidly changing global business environments, suggests that technology venturing is becoming an important paradigm in world economics. Technology venturing is where entrepreneurs establish new businesses with relatively small amounts of angel, venture capital, and other capital investment to commercialize innovative technology/knowledge/business ideas into viable business models. Technology venturing is becoming an important force in global businesses and economies as developed and developing nations seek policies and measures to vitalize ventures to accelerate regional economic development. A critical component of technology venturing is technology transfer or the commercialization of technology/knowledge/ideas as products and/or services.

Since the 1970s, science parks and technology incubators have been financed and developed by public and private sectors as an important strategy to facilitate technology transfer and to ultimately create venture businesses, [2,3]. A main objective of science parks and incubators is often to promote the application of science by bridging the gap between research and development (R\&D) and commercialization. Theoretically, a linear model, in which there is a chain of successive interrelated activities, has been the most dominant justification for building science parks and incubators. The model begins with basic research and passes through applied and more developmental research activities, the development of new product and process ideas, the evolution and testing of prototypes, to commercial production, and finally to markets and diffusion [4].

While the linear model has been the dominant approach in the technology policy of regions and nations, increasing numbers of researchers and practitioners have been proposing other approaches to accelerate technology transfer and commercialization [5-8]. For example, many ventures come from innovations in the experimental development or production stages rather than in basic research. Such nonlinear models are gaining credibility as better reflecting real world practice. However, there has been little empirical research that contrasts venture businesses growth based on linear and nonlinear models.

The purposes of this article are fourfold: (1) to explore the characteristics of Korean venture business and entrepreneurs to describe existing technology transfer practices, (2) to assess whether start-up companies in Daejeon, Korea, conform to the linear or nonlinear models, (3) to identify what companies conform to the linear or nonlinear models and what factors seem to affect start-ups, growth, and success, and (4) to suggest more effective venture business policies and strategies.

\section{Literature review}

\subsection{Science parks, incubators, and business ventures}

Korea's unprecedented economic growth, from 1960 to 1995, is largely attributed to chabol (groups of large companies) with the assistance of favorable policy of the central government 
and having key resources assembled for a unified and directed approach. But it is also accepted that much of Korea's economic difficulty can also be blamed on chabol and Korea's central government, because these large bureaucratic institutions cannot effectively respond to rapid environmental changes as well as to foster entrepreneurship [9]. This is one of the main reasons why high-technology business venturing is attracting so much attention from Korea's business, government, and academic sectors. Academicians and practitioners are beginning to consider high-technology venture businesses as being an attractive alternative to the chabol system [10-12].

Venture business is knowledge and technology intensive, making this an especially attractive alternative since it addresses the challenges of high cost and low efficiency that are currently quite prevalent the Korean economy. By their very nature, successful and sustainable venture businesses advocate labor savings as well as high profitability $[13,14]$. The vision is one of having prominent Korean venture businesses creating new fastgrowth firms and high-value jobs, thereby restructuring the Korean economy to be more robust, contributing to balanced trade, and to ultimately bringing the Korean economy back to prosperity. Accordingly, the Korean government is actively seeking strategies to vitalize venture businesses, especially in high-technology industries, to recover from the current economic crisis, and to better prepare for the 21 st-century information/knowledge society.

Venture business are defined and described differently [15]. For example, the United States emphasizes labels like high-technology small firm (HTSF) or new technology-based firm (NTBF) as venture business while Japan legally recognizes a venture business as a firm that invests more than $3 \%$ of total sales in R\&D. In general, venture business can be defined as start-up business that a small of number of entrepreneurs establishes based on core competencies and/or high technologies to gain high returns despite high risk $[9,16]$. According to the Korea Institute of Economy and Technology (KIET) report [17], Korean regulations state that a firm is a venture business if the firm invests more than $5 \%$ of total sales into R\&D, or if sales on patent account for more than $50 \%$ of total sales, or if venture capital is greater than $20 \%$ of stockholders' equity, or if stocks undertaken by venture capital are more than $10 \%$ of stockholders' equity.

If successful, venture businesses can bring high profits, create new and high-paying jobs, open new markets, and facilitate technology development. The success rate of venture businesses worldwide is reported to be around 20\% [18]. But, if adequately supported by the national and local governments and universities, research institutes, and other related institutions, it is reported that the success rate can be as high as 50\% [19,20].

To foster technology development and to transfer technologies into business ventures, one of the more popular and attractive policies has been to build industrial and/or research parks, better known as science parks, to build close linkage among governments, universities, research institutes, and corporations in order to speed the innovating new technology and products, to transfer and commercialize technology and products, and to support ventures and incubate small businesses [21-24].

A less expensive alternative to building and maintaining science parks is to build business incubators that provide entrepreneurs with advice and counsel and serve as "networking 
centers" to access talent, technology, capital, and business know-how. Typically, incubator programs are housed in incubator centers in which companies can co-locate, rent space, and share business services and equipment [25]. In other words, incubators nurture young firms, helping them to survive and grow during the start-up period when they are most vulnerable. Incubators provide hands-on management assistance, access to financing, and orchestrated exposure to critical business or technical support services. They also offer entrepreneurial firms shared office services, access to equipment, flexible leases, and expandable space_-all under one roof [26].

Whether labeled a technology or business incubator, a key metric of success is the accelerated growth of companies in a variety of technology-based industries. To attain these ends, incubators offer targeted service packages that include strategic advice, access to financing, marketing, and PR support, benefits programs, mentoring, and what comes close to "turn-key" infrastructure support. Incubators can and do provide a wide array of services that give resident companies a competitive advantage over other start-ups including access to advice from community leaders, in-house consulting, financing referrals, marketing, and PR aid, key infrastructure support, and more.

\subsection{Linear and nonlinear models}

At the core of the science park or incubator models is an underpinning view about how technologies are created, transferred, and commercialized, in a linear model. The model begins with basic scientific research and passes through applied and more developmental research activities, to the development of new product and process ideas, followed by the evolution and testing of prototypes, to commercial production, and finally to diffusion [4]. Thus, science parks and incubators are needed to facilitate the process of implementation and commercialization of leading-edge technologies to marketable products or services. This ideal-type scenario is the main reason why the Korean government has funded major efforts to build science parks and incubators throughout the country.

However, there is also a counter "ideal-type model" of technology transfer to business ventures, more of a nonlinear model [5-8]. According to Massey et al. [4], there are five major critiques of the linear model. First, there is not just one process of innovation. Second, key research does not just occur at the initiator stage. Third, rather than just being used as the "eureka" or beginning point of the innovation process, research results can be used, in one form or another, at all stages of innovation. Fourth, the relationship between basic research and commercialization is too complex to be understood as a linear relationship. Fifth, the linear model devalues the contributions of a range of participants crucial to and tangentially involved in the innovation process. For example, users of the innovation and whose ideas and consequent changes of processes and products can be another starting point for subsequent innovations.

While it is quite common for scholars to emphasize the appropriateness of one model and the inappropriateness of the other model, there is considerable evidence that both the linear and nonlinear models provide reasonable frameworks for understanding innovation process $[4-8]$. 


\subsection{Critical success factors for business ventures and incubators}

Most studies of business ventures and incubators suggest a number of important factors or issues that may be considered as success factors [6,7,9-11,13,15-17,19,25,27-33] such as:

- low cost of office space,

- management services offered,

- low cost of utility services

- administration and financial services provided,

- leadership of the incubator,

- support from the local university and research institutes,

- support from government and public sector organizations,

- financial support including angel, venture, and other sources of capital,

- market conditions and marketing capability,

- the entrepreneurial atmosphere,

- networks with local businesses and support services,

- global networks for information sharing,

- quality of business plans,

- management capacity,

- location of the incubator,

- the availability and quality of technical experts.

Success of business ventures is difficult to define in a comprehensive and measurable manner. Some argue that survival rate is the best measure for success $[25,26]$. However, the problem with survival rate is longevity: survival after 2, 3, or 10 years? Many "successful" firms were sold to other firms and there are many cases of merger and acquisitions [26]. Since we do not have proper surrogate measures for success of business venture, a more traditional and proven approach was adopted. Most studied organizational level measures are converged into two types. The first is profit [34-40], while the second is several kinds of ratios such as return on assets, return on investment, cost/benefit ratio, internal rate of return [41-46]. In this study, both types of measures were combined.

Success of business venture $=$ Average of (sales growth rate, employee growth rate, $\mathrm{R} \& \mathrm{D}$ growth rate, investment growth rate)

\section{Research methodology}

\subsection{Sample}

The metropolitan area of Daejeon, Korea, was selected as the research location. This is because (1) Daejeon is well known as a center of Korea's high-technology R\&D as a result of 
long-term government support for Taedok Science Town that is located in the Daejeon area, (2) Daejeon has been a center of technology venture businesses since 1998, and (3) one of researchers is located in Daejeon and has been associated with local venture associations and venture capital, which facilitated in-depth research as well as successful data collection and a high response rate.

All business ventures that started in Daejeon since 1995 were chosen as the initial sample frame because 1995 was a key year when the Korean government emphasized the importance of Korean ventures [17,22]. About 200 companies were identified by the Daejeon Chamber of Commerce for the period of 1995-2000. To avoid any contamination on the sample, research assistants checked actual existence and current condition of each company listed on the sample frame. More than 50 companies had gone bankrupt and about 30 companies had gone through mergers and acquisitions. One hundred and twenty-one venture companies were left after the elimination process and designated as the target sample.

\subsection{Data collection}

A preliminary version of the questionnaire was pilot-tested for accuracy and reliability with target respondents. Each respondent reviewed the questionnaire in the presence of one of the researchers and provided feedback regarding wording, understandability, and applicability of the instrument. The original questionnaire utilized seven-point Likert scales, but the pilot-test respondents preferred the five-point scale that was adopted for the study.

In the spring of 2000, questionnaires were administered to 121 graduates or tenants of seven technology business incubators in the Daejeon metropolitan area. To secure high response rate, phone calls were made to top managers to solicit participation before questionnaire mailing. Two weeks after mailing, phone calls were made to unanswered companies to re-solicit their participation. If needed, questionnaires were re-mailed and collected by research assistants. Out of 121 questionnaires, 118 were returned. The final response rate was $97.5 \%$. This high response rate is primarily attributed to high visibility and involvement of one of our researchers in Daejeon's venture businesses. Demographic analyses did not reveal any significant sample bias.

\section{Results}

\subsection{Demographic analysis}

As summarized in Table 1, most Korean venture businesses were established after 1998. This reflects the changes of policy-making of the central government after the economic crisis in late 1997 from chabol-oriented policies to policies that are more favorable to business ventures. High-technology industries including software and telecommunication (35.0\%), biomedical (19.2\%), computers (16.7\%), and semiconductors (10.8\%) were the most popular venture business choices. Most new venture start-ups were in some way related to previous business and technology experiences $(92.8 \%)$ of the lead entrepreneur. This finding supports 
Table 1

Demographic analysis of venture businesses (\%)

\begin{tabular}{|c|c|c|c|c|}
\hline Starting year & Industry & $\begin{array}{l}\text { Association with } \\
\text { previous experience }\end{array}$ & Venture type & $\begin{array}{l}\text { Focus of } \\
\text { innovation }\end{array}$ \\
\hline $1996(4.3)$ & semiconductor (10.8) & same industry (33.3) & $\begin{array}{l}\text { production } \\
\text { innovation (41.5) }\end{array}$ & $\begin{array}{l}\text { basic technology } \\
\text { (12.6) }\end{array}$ \\
\hline $1997(16.2)$ & computers (16.7) & very close (37.8) & & $\begin{array}{l}\text { applied technology } \\
(55.0)\end{array}$ \\
\hline $1998(36.8)$ & $\mathrm{SW} / \mathrm{TC}(35.0)$ & related (21.6) & $\begin{array}{l}\text { technology } \\
\text { commercialization } \\
(43.2)\end{array}$ & $\begin{array}{l}\text { pilot development } \\
(22.5)\end{array}$ \\
\hline 1999 (35.9) & biomedical (19.2) & not related (7.2) & & production (9.9) \\
\hline $2000(6.8)$ & others $(28.3)$ & & other (15.3) & \\
\hline
\end{tabular}

other research that contends that spin-offs are the dominant sources of venture business startups $[47-50]$.

Innovation was reported to occur all along the technology transfer processes as follows: application (55.0\%), pilot development (22.5\%), basic technology research $(12.6 \%)$, and production $(9.9 \%)$ stages. These data suggest that a nonlinear model is quite prevalent in the real venture world. In addition, the survey results on venture type, as identified by the respondent, show that technology commercialization (linear model) and product innovation (nonlinear model) are almost the same $(43.2 \%$ vs. $41.5 \%)$. These responses confirm the widespread use of the nonlinear model.

Most of the sample business ventures have annual sales less than US\$1 million, employ less than 10 people, have $\mathrm{R} \& \mathrm{D} /$ capital ratio of around $30 \%$, and invested about US $\$ 1$ million initially. These survey results also show that most venture companies show profiles of typical small high-technology business; small amount of sales with fast growth, small number of employees with high growth, high R\&D ratio with constant growth, and small amount of investment with relatively high growth.

\subsection{Characteristics of entrepreneurs}

There have been a number of studies examining characteristics and importance of entrepreneurship [5-8,16,51-59]. The second part of questionnaire was designed to identify characteristics of Korean entrepreneurs and Korean entrepreneurship.

Table 2 shows the prevalence of males in venture businesses (93.4\%) and confirms the cultural heritage of male dominance in Korean business society. This trend is believed to be weakening as females are beginning to actively participate in venture businesses since the late $1990 \mathrm{~s}$. The thirties is the most dominant age group for venture start-ups $(52.2 \%)$, followed by the 20 -year-olds, and then the 40 -year-olds. Only $4.3 \%$ of the respondents account for venture start-ups after the age 45. Eighty-five percent of the entrepreneurs have no prior venture experience, which would seem to argue of the importance of entrepreneur support structure. In short, there is the dominant scenario of "young male entrepreneurs with not much business and 
Table 2

Characteristics of entrepreneurs (\%)

\begin{tabular}{|c|c|c|c|c|c|}
\hline Gender (\%) & $\begin{array}{l}\text { Age at } \\
\text { start-up (\%) }\end{array}$ & Education (\%) & Major (\%) & $\begin{array}{l}\text { Previous } \\
\text { expertise (\%) }\end{array}$ & $\begin{array}{l}\text { Previous } \\
\text { institution (\%) }\end{array}$ \\
\hline Male (93.4) & under $25(0.9)$ & $\begin{array}{l}\text { high school } \\
(1.7)\end{array}$ & $\begin{array}{l}\text { liberal arts and social } \\
\text { sciences }(9.4)\end{array}$ & $\mathrm{R} \& \mathrm{D}(54.8)$ & $\begin{array}{l}\text { educational } \\
(13.9)\end{array}$ \\
\hline \multirow[t]{5}{*}{ Female (6.6) } & $25-30(22.6)$ & $\begin{array}{l}\text { bachelor's } \\
\text { degree }(51.3)\end{array}$ & $\begin{array}{l}\text { natural science and } \\
\text { engineering (82.1) }\end{array}$ & technical (15.7) & $\begin{array}{l}\text { private sector } \\
(32.2)\end{array}$ \\
\hline & $31-35(26.1)$ & $\begin{array}{l}\text { master's degree } \\
(30.8)\end{array}$ & others $(8.5)$ & students (10.4) & $\begin{array}{l}\text { public sector } \\
(4.4)\end{array}$ \\
\hline & $36-40(26.1)$ & $\mathrm{PhD}(16.2)$ & & clerical (4.4) & $\begin{array}{l}\text { research institute } \\
(42.6)\end{array}$ \\
\hline & $41-45(20.0)$ & & & sales (5.2) & other $(7.0)$ \\
\hline & Over 45 (4.3) & & & others $(9.6)$ & \\
\hline
\end{tabular}

management experience managing a start-up business and taking on risky business decisions and challenges while hoping for high rates of return."

Based on the Daejeon sample, Korean entrepreneurs generally received a high level of education-16.2\% have PhDs, 30.8\% have master's degree, and 51.3\% have bachelor's degree. The majority of entrepreneurs in the sample majored in natural science or in engineering. This result confirms the accepted belief that most venture businesses are technology oriented and that the entrepreneurs usually have knowledge in specific technologies.

Prior to venture start-ups, most of entrepreneurs were engaged in R\&D (54.8\%) and technical (15.7\%) work. Many moved out of research institutes $(42.6 \%)$ and educational institutions (13.9\%). One-third of venture start-ups were spin-offs from the private sector. These results support the common assumption that venture ideas stem from leading-edge research or technology. In general, the survey results also confirm the conclusions of previous studies on the characteristics of entrepreneurs in other countries.

However, venture start-ups based on linear and nonlinear models show quite different profiles on the characteristics of age at start-up, education, previous job, and previous institution. While $60 \%$ of linear-based start-ups established their business at the $35-45$ age group, $61.5 \%$ of nonlinear-based start-ups established theirs at the $25-35$ age group. In brief, there is a tendency of older entrepreneurs to be more strongly represented in the linear model, which may reflect the fact that innovations in basic research require a different skill set and range of experience than innovations that occur in later stages of the innovation process.

Entrepreneurs representing the linear model also tend to have higher levels of education than entrepreneurs representing nonlinear models. While $28 \%$ of entrepreneurs on linear model have $\mathrm{PhDs}, 42 \%$ have master's degree, $30 \%$ have bachelor's degrees, only $7.5 \%$ of entrepreneurs on nonlinear model have PhDs, 22\% have master's degree, and $67 \%$ have bachelor's degree. Again, this result supports the fact that linear-based start-ups came from basic R\&D, thus correlating with higher education.

Although statistical analysis does not show much difference on academic major, $92 \%$ of entrepreneurs on linear model majored in natural science and engineering, while $74.2 \%$ of entrepreneurs on nonlinear model did. As expected, previous jobs show vast difference 
between two types of start-ups; $70.6 \%$ and $9.8 \%$ of entrepreneurs on linear-based start-ups had previous jobs in R\&D and technical fields, respectively, compared to $42.2 \%$ and $20.3 \%$, respectively, of entrepreneurs in non-linear-based start-ups. This result reinforces the importance of basic R\&D in linear model.

Similar observations could be made on the previous employers of entrepreneurs; $58.8 \%$ and $35.5 \%$ of entrepreneurs on linear-based start-ups came from research institutes and private companies, respectively, while $37.5 \%, 29.7 \%$, and $17.2 \%$ of entrepreneurs on non-linear-based start-ups came from private companies, research institutes, and educational institutions, respectively. There were no noticeable differences between the two types of start-ups on previous venture experience.

The above analysis shows that there were noticeable differences on the characteristics of Korean entrepreneurs between linear and nonlinear models and provides the basis of dividing the sample into two groups: linear and nonlinear. In addition, in-depth analyses of influences on start-ups and contributions on growth of success factors by linear and nonlinear models would lead to suggest different venture-nurturing strategies for each model.

\section{Discussions}

\subsection{Influence of success factors on start-up}

The survey asked entrepreneurs to what degree a range of factors influenced their "success" with their venture start-up? Entrepreneurs rated "business plan" as the most influential success factor, followed by "strong entrepreneurship and leadership," "technical experts," "management capacity," and "location" (refer to Table 3). "Financial support," "global network for information sharing," "leadership of incubator," and "networking with local businesses," all of which have been cited as distinguished features of science parks and incubators, were rated as the least influential success factors. These results also imply that Korean entrepreneurs consider their capacity and the quality of their technology as the most critical resources for venture start-up success, rather than functions and features of science parks and incubators. On the whole, entrepreneurs representing both the linear and nonlinear models ranked influence of success factors on start-up activities in a similar manner.

This could be interpreted as simply strong egos believing "they did it all" or a healthy sign for venture businesses in Korea where the entrepreneurs are tending to seek independence and self-sustaining routes to success rather than leaning on government or other external support. There have been doubts about the true intent of Korean entrepreneurs and venture businesses due to strong government support and policy, favorable support from financial institutions, and popularity of venture businesses. In short, some experts suspect that Korean entrepreneurs are not real entrepreneurs in that they simply take chances only with outside funding and help with little risk to themselves [11,20].

To check whether there were noticeable differences on evaluating influence of success factors with entrepreneurs representing linear and nonlinear models, $t$ tests were performed. In general, entrepreneurs following the nonlinear model evaluated success factors slightly more 
Table 3

Influence of success factors on start-up

\begin{tabular}{llllll}
\hline Success factors & All & Linear & Nonlinear & $t$ Statistics & Probability \\
\hline Low-cost space offer from incubator & 3.252 & 3.196 & 3.277 & -0.308 & .759 \\
Management services by incubator & 2.975 & 2.600 & 3.277 & -3.394 & .001 \\
$\quad$ Utility services by incubator & 3.160 & 2.980 & 3.333 & -1.795 & .075 \\
$\quad$ Administrative and financial & 2.941 & 2.560 & 3.215 & -3.283 & .001 \\
$\quad$ services by incubator & & & & & \\
$\quad$ Leadership of incubator & 2.756 & 2.333 & 3.123 & -3.919 & .000 \\
$\quad$ Support from university and & 2.882 & 2.569 & 3.123 & -2.389 & .019 \\
$\quad$ research institute & & & & \\
Support from government and & 2.908 & 2.804 & 2.985 & -0.784 & .435 \\
$\quad$ public sector & & & & & \\
Financial support from venture capital & 2.362 & 1.979 & 2.615 & -2.501 & .014 \\
$\quad$ Market conditions & 2.805 & 2.500 & 3.015 & -2.224 & .028 \\
$\quad$ Entrepreneur atmosphere & 2.958 & 2.760 & 3.077 & -1.293 & .199 \\
$\quad$ Network with local businesses & 2.788 & 2.420 & 2.985 & -2.230 & .024 \\
$\quad$ Global network for information sharing & 2.633 & 2.360 & 2.776 & -1.784 & .077 \\
Strong entrepreneurship and leadership & 3.551 & 3.600 & 3.492 & 0.464 & .644 \\
Business plan & 3.681 & 3.647 & 3.677 & -0.146 & .884 \\
$\quad$ Management capacity & 3.393 & 3.280 & 3.516 & -1.068 & .288 \\
$\quad$ Location & 3.376 & 3.163 & 3.492 & -1.512 & .134 \\
$\quad$ Marketing capability & 3.153 & 2.840 & 3.354 & -2.494 & .014 \\
Technical experts & 3.462 & 3.600 & 3.406 & 0.810 & .420 \\
\hline
\end{tabular}

influential than entrepreneurs following the linear model. Entrepreneurs on nonlinear model rated the following success factors as more influential on their start-up decisions: "management services," "utility services," "administrative and financial services," "leadership of incubator," "support from universities and research institutes," "financial support from venture capital," "market conditions," "global network for information sharing," and "marketing capability." This result suggest that entrepreneurs following the nonlinear model have slightly greater expectations about the roles, functions, and services of science parks and incubators than do entrepreneurs following linear models. It may be interpreted that linear model entrepreneurs think technology itself is more important since they rely more on leadingedge technology while nonlinear model entrepreneurs believe production and marketing are more critical since they depend upon the commercialization of more established technologies.

\subsection{Contributions of success factors on growth}

The survey asked entrepreneurs how much did each success factor actually contribute to the growth of their venture businesses? This is important since the previous section deals with the influence of factors for start-up while this question deals with actual contribution of success factors on firm growth.

The most contributing success factor to growth was "business plan," followed by "strong entrepreneurship and leadership," "technical experts," "low-cost space," and "management 
capacity" (refer to Table 4). "Financial support," "leadership of incubator," "market conditions," "global network for information sharing," and "network with local business" were rated as the least contributing success factors for firm growth. These results were almost identical to the survey results on influence of success factors on start-up. These results show that entrepreneurs consider their own capacity and that of their technologies as the most important resources for venture growth, rather than functions and features of science parks and incubators. Again, this may be interpreted as a bias on the part of the entrepreneurs that they "they think they did it all." Science parks and incubators may have contributed more to their success than the entrepreneurs realize or report.

Unlike influence of success factors, this could be interpreted as very unhealthy sign for venture business policy and strategy in Korea. Once entrepreneurs established venture businesses with their own resources such as good business plan, strong entrepreneurship, management capacity, and technical experts, then additional outside help needs to be targeted to accelerate the growth of the venture. Korean government has put enormous amount of tax money into venture capital and building science parks and incubators, but these efforts have not paid off except providing low-cost space. There have been news reports of strong government support and policy, favorable support from financial institutions, and other fringe benefits for venture businesses. However, these survey results contradict these reports. Indeed, some experts have reported that Korean government policies on venture businesses are not succeeding and asked for more effective policy-making [10,12,16].

Table 4

Contribution of success factors on growth

\begin{tabular}{llllll}
\hline Success factors & All & Linear & Nonlinear & $t$ Statistics & Probability \\
\hline Low-cost space offer from incubator & 3.500 & 3.471 & 3.500 & -0.138 & .891 \\
Management services by incubator & 3.017 & 2.740 & 3.281 & -2.997 & .003 \\
Utility services by incubator & 3.193 & 2.960 & 3.394 & -2.106 & .037 \\
Administrative and financial services & 2.958 & 2.700 & 3.185 & -2.562 & .012 \\
$\quad$ by incubator & & & & & .000 \\
Leadership of incubator & 2.754 & 2.360 & 3.092 & -3.964 & .191 \\
Support from university and & 3.061 & 2.896 & 3.188 & -1.316 & .447 \\
$\quad$ research institute & & & & & \\
Support from government and & 3.043 & 2.939 & 3.108 & -0.764 & .023 \\
$\quad$ public sector & & & & & .045 \\
Financial support from venture capital & 2.377 & 2.043 & 2.609 & -2.302 & .074 \\
Market conditions & 2.816 & 2.551 & 3.000 & -2.029 & .043 \\
Entrepreneur atmosphere & 3.035 & 2.816 & 3.206 & -1.804 & .032 \\
Network with local businesses & 2.897 & 2.612 & 3.047 & -2.050 & .546 \\
Global network for information sharing & 2.853 & 2.551 & 3.031 & -2.176 & .941 \\
Strong entrepreneurship and leadership & 2.684 & 3.776 & 3.645 & 0.607 & .411 \\
Business plan & 3.767 & 3.796 & 3.781 & 0.075 & .357 \\
Management capacity & 3.461 & 3.388 & 3.556 & -0.826 & .364 \\
Location & 3.412 & 3.313 & 3.492 & -0.924 & .134 \\
Marketing capability & 3.235 & 3.122 & 3.317 & -0.911 & 1.511 \\
Technical experts & 3.579 & 3.796 & 3.452 & & \\
\hline
\end{tabular}


To check whether there were noticeable differences on evaluating contribution of success factors between entrepreneurs on linear model and entrepreneurs on nonlinear model, $t$ test was performed. In general, entrepreneurs on the non-linear model evaluated contributing factors slightly higher than entrepreneurs on the linear model. Entrepreneurs on nonlinear model considered the following success factors to contribute more to the growth of their businesses: "management services," "utility services," "administrative and financial services," "leadership of incubator," "support from government and public sector," "financial support from venture capital," "market conditions," "entrepreneur atmosphere," "network with local businesses," and "global network for information sharing."

\subsection{Influence vs. contribution of success factors}

The final analysis concentrated on whether entrepreneurs recognize considerable differences between influence and contribution of each success factor. In general, entrepreneurs evaluated contribution of success factors more highly than influence, but there were no noticeable differences except on "low-cost space offer" and "global network for information sharing" (refer to Table 5). Initially, entrepreneurs did not think that the cost of space was a serious concern, but they realized the importance of cost of space after their start-up stage. In this sense, the most critical and contributing function of incubator seems to be low-cost space offer for venture businesses. The same logic may apply to global network for information

Table 5

Influence vs. contribution of success factors

\begin{tabular}{|c|c|c|c|c|}
\hline Success factors & Influence & Contribution & $t$ Statistics & Probability \\
\hline Low-cost space offer from incubator & 3.252 & 3.500 & -1.897 & .060 \\
\hline Management services by incubator & 2.975 & 3.017 & -0.453 & .652 \\
\hline Utility services by incubator & 3.160 & 3.193 & -0.193 & .847 \\
\hline $\begin{array}{l}\text { Administrative and financial services } \\
\text { by incubator }\end{array}$ & 2.941 & 2.958 & -0.274 & .785 \\
\hline Leadership of incubator & 2.756 & 2.754 & 0.253 & .801 \\
\hline $\begin{array}{l}\text { Support from university and } \\
\text { research institute }\end{array}$ & 2.882 & 3.061 & -1.016 & .312 \\
\hline $\begin{array}{l}\text { Support from government and } \\
\text { public sector }\end{array}$ & 2.908 & 3.043 & -1.311 & .193 \\
\hline Financial support from venture capital & 2.362 & 2.377 & 0.000 & 1.000 \\
\hline Market conditions & 2.805 & 2.816 & 0.212 & .832 \\
\hline Entrepreneur atmosphere & 2.958 & 3.035 & -0.988 & .325 \\
\hline Network with local businesses & 2.788 & 2.897 & -1.045 & .298 \\
\hline Global network for information sharing & 2.633 & 2.853 & -1.945 & .054 \\
\hline Strong entrepreneurship and leadership & 3.551 & 2.684 & -1.519 & .132 \\
\hline Business plan & 3.681 & 3.767 & -1.463 & .146 \\
\hline Management capacity & 3.393 & 3.461 & -0.706 & .482 \\
\hline Location & 3.376 & 3.412 & -0.476 & .635 \\
\hline Marketing capability & 3.153 & 3.235 & -0.965 & .337 \\
\hline Technical experts & 3.462 & 3.579 & -1.085 & .280 \\
\hline
\end{tabular}


sharing. Entrepreneurs may not recognize the importance of global networking beforehand, but realize that information on global market and information sharing through this network is essential to their growth.

\subsection{Contribution of factors on success of business ventures}

To assess the explanatory power of characteristics of entrepreneurship on success of venture businesses, analysis of variances (ANOVA) was performed. The analysis shows that differences in industry, education, age at start-up, prior expertise, and previous institution do

Table 6

Regression analysis of influence of success factors on success

\begin{tabular}{|c|c|c|c|c|c|c|}
\hline \multirow[t]{2}{*}{ Success factors } & \multicolumn{2}{|l|}{ All } & \multicolumn{2}{|l|}{ Linear } & \multicolumn{2}{|l|}{ Nonlinear } \\
\hline & Coefficient & $t$ Value & Coefficient & $t$ Value & Coefficient & $t$ Value \\
\hline $\begin{array}{l}\text { Low-cost space offer } \\
\text { from incubator }\end{array}$ & .0577 & 0.70 & .3108 & $1.99 * *$ & -.0932 & -1.03 \\
\hline $\begin{array}{l}\text { Management services } \\
\text { by incubator }\end{array}$ & -.0754 & -0.49 & .3188 & 0.97 & -.1276 & -0.79 \\
\hline Utility services by incubator & .0041 & 0.03 & -.0118 & -0.04 & .2864 & 1.58 \\
\hline $\begin{array}{l}\text { Administrative and financial } \\
\text { services by incubator }\end{array}$ & .2723 & $1.65 *$ & -.1723 & -0.49 & .1449 & 0.72 \\
\hline Leadership of incubator & -.1642 & -1.13 & -.2855 & -0.92 & -.0460 & -0.29 \\
\hline $\begin{array}{l}\text { Support from university and } \\
\text { research institute }\end{array}$ & -.0668 & -0.54 & -.0668 & -0.25 & -.1536 & -1.06 \\
\hline $\begin{array}{l}\text { Support from government and } \\
\text { public sector }\end{array}$ & -.0323 & -0.26 & -.0153 & -0.08 & .0269 & 0.13 \\
\hline $\begin{array}{l}\text { Financial support from } \\
\text { venture capital }\end{array}$ & -.0120 & -0.11 & .3503 & $1.80 * *$ & .0166 & 0.10 \\
\hline Market conditions & .2088 & $1.68 *$ & .2035 & 1.05 & -.0302 & -0.16 \\
\hline Entrepreneur atmosphere & .1100 & 1.10 & -.3261 & -1.61 & .3490 & $2.73 * * *$ \\
\hline Network with local businesses & -.0562 & -0.49 & .3616 & 1.24 & -.1141 & -0.89 \\
\hline $\begin{array}{l}\text { Global network for } \\
\text { information sharing }\end{array}$ & .2015 & 1.63 & -.1294 & -0.42 & .0762 & 0.51 \\
\hline $\begin{array}{l}\text { Strong entrepreneurship } \\
\text { and leadership }\end{array}$ & -.3257 & $-2.04 * *$ & .0443 & 0.14 & -.5633 & $-3.12 * * *$ \\
\hline Business plan & .3390 & $1.86 *$ & .1605 & 0.51 & .3675 & 1.57 \\
\hline Management capacity & .0695 & 0.44 & .0600 & 0.22 & .2762 & 1.32 \\
\hline Location & .0098 & 0.07 & .1799 & 0.79 & -.4431 & $-2.10 * *$ \\
\hline Marketing capability & .2275 & $1.78 *$ & -.1591 & -0.74 & .6177 & $3.11 * * *$ \\
\hline Technical experts & .2695 & $2.14 * *$ & .0577 & 0.28 & .4384 & $2.64 * *$ \\
\hline$R^{2}(\%)$ & 48.3935 & & 55.6714 & & 71.9116 & \\
\hline$F$ value & 4.58 & & 1.95 & & 5.83 & \\
\hline $\operatorname{Pr}>F$ & .0001 & & .0542 & & .0001 & \\
\hline
\end{tabular}

* Statistically significant at the level of alpha $=.10$.

** Statistically significant at the level of alpha=.05.

$* * *$ Statistically significant at the level of alpha $=.01$. 
not have statistically significant association with the success of business ventures. Thus, these variables were excluded from further analysis.

To investigate importance of success factors on success of business ventures, regression analysis was performed (refer to Table 6). Influence of success factors in total has very significant explanatory power for success of business venture (above $48 \%$ of $R^{2}$ and $F$ value of 4.58). "Strong entrepreneurship and leadership," "technical experts," "administrative and financial services," "market conditions," and "business plan" were statistically significant in explaining success of business venture.

In case of linear model-based ventures, "low-cost space offer" and "financial support from venture capital" were the success factors that lead to venture success while "entrepreneur

Table 7

Regression analysis of contribution of success factors on success

\begin{tabular}{|c|c|c|c|c|c|c|}
\hline \multirow[t]{2}{*}{ Success factors } & \multicolumn{2}{|l|}{ All } & \multicolumn{2}{|l|}{ Linear } & \multicolumn{2}{|l|}{ Nonlinear } \\
\hline & Coefficient & $t$ Value & Coefficient & $t$ Value & Coefficient & $t$ Value \\
\hline $\begin{array}{l}\text { Low-cost space offer } \\
\text { from incubator }\end{array}$ & .1549 & $1.71 *$ & .4768 & $2.36 * *$ & .0337 & 0.31 \\
\hline $\begin{array}{l}\text { Management services } \\
\text { by incubator }\end{array}$ & .1248 & 1.06 & .5434 & $1.79 *$ & .0529 & 0.37 \\
\hline Utility services by incubator & .0327 & 0.35 & -.3093 & -1.08 & .0602 & 0.54 \\
\hline $\begin{array}{l}\text { Administrative and financial } \\
\text { services by incubator }\end{array}$ & .2228 & $1.72 *$ & .1700 & 0.66 & .5499 & $2.95 * * *$ \\
\hline Leadership of incubator & .0734 & 0.65 & .0248 & 0.09 & .0125 & 0.09 \\
\hline $\begin{array}{l}\text { Support from university and } \\
\text { research institute }\end{array}$ & .0650 & 0.58 & -.0209 & -0.09 & .1195 & 0.72 \\
\hline $\begin{array}{l}\text { Support from government and } \\
\text { public sector }\end{array}$ & .0557 & 0.49 & .0549 & 0.32 & -.0464 & -0.25 \\
\hline $\begin{array}{l}\text { Financial support from } \\
\text { venture capital }\end{array}$ & -.1048 & -1.25 & .0426 & 0.25 & -.1039 & -0.94 \\
\hline Market conditions & .1150 & 1.28 & .1255 & 0.67 & .1099 & 0.88 \\
\hline Entrepreneur atmosphere & .0625 & 0.65 & .0831 & 0.53 & .0923 & 0.59 \\
\hline Network with local businesses & -.0204 & -0.17 & .0841 & 0.39 & -.2278 & -1.23 \\
\hline $\begin{array}{l}\text { Global network for } \\
\text { information sharing }\end{array}$ & .2159 & $1.90 *$ & .0432 & 0.20 & .3019 & $1.87 *$ \\
\hline $\begin{array}{l}\text { Strong entrepreneurship } \\
\text { and leadership }\end{array}$ & -.1199 & -0.90 & .2634 & 0.90 & -.2986 & $-1.91 *$ \\
\hline Business plan & .2694 & $1.77 *$ & -.0194 & -0.06 & .2758 & 1.54 \\
\hline Management capacity & -.0484 & -0.40 & -.2726 & -0.97 & .1070 & 0.72 \\
\hline Location & .0158 & 0.14 & .2773 & 1.31 & -.1841 & -1.19 \\
\hline Marketing capability & .3082 & $2.95 * * *$ & .3203 & 1.31 & .2466 & $1.69 *$ \\
\hline Technical experts & .0369 & 0.38 & -.2225 & -0.91 & .1562 & 1.16 \\
\hline$R^{2}(\%)$ & 64.3197 & & 68.0166 & & 75.7560 & \\
\hline$F$ value & 8.61 & & 3.07 & & 7.12 & \\
\hline $\operatorname{Pr}>F$ & .0001 & & .0046 & & .0001 & \\
\hline
\end{tabular}

* Statistically significant at the level of alpha $=.10$.

$* *$ Statistically significant at the level of alpha $=.05$.

$* * *$ Statistically significant at the level of alpha $=.01$. 
atmosphere," "strong entrepreneurship and leadership," "location," "marketing capability," and "technical experts" were strong explanatory factors for non-linear-based ventures. As discussed in the previous section, this regression analysis confirms the fact that marketing and administrative factors were more critical for non-linear-based ventures. Negative coefficients such as "strong entrepreneurship and leadership" and "location" seem to be the results of multicolinearity among independent variables (success factors).

To investigate importance of contribution of success factors on success of business venture, regression analysis was performed (refer to Table 7). The contribution of success factors in total shows statistically significant explanatory power for success of business venture $(64.32 \%$ of $R^{2}$ and $F$ value of 8.61). "Low-cost space offer," "administrative and financial services," "global network for information sharing," "marketing capability," and "business plan" were statistically significant in explaining success of business venture.

In case of linear model-based ventures, "low-cost space offer" and "management services" were the success factors that lead to venture success while "administrative and financial services," "global network for information sharing," "marketing capability," and "strong entrepreneurship and leadership" were strong explanatory success factors for non-linear-based ventures. These results were quite different from analysis on influence of success factors. It is probable that administrative and managerial services offered by incubators were appreciated at start-ups, but these services actually contribute to venture success as the venture business progress. Again, negative coefficients seem to be the results of multicolinearity among independent variables (success factors).

\section{Policy implications and conclusions}

This research has several important policy implications. First, policy-makers and managers of science parks and technology incubators should recognize the prevalence of both linear- and non-linear-based venture businesses and devise appropriate support policy for these types of ventures. Second, while success to linear-based business venture seems to be focused on knowledge or technology itself, success of non-linear-based business venture is believed to be more management-oriented (marketing, administration, etc.). Thus, support activities should be focused to augment these services. Third, the policy of "as much services possible to all venture businesses" should be changed to "pinpoint services to each venture business" as entrepreneurs seem to have good understanding of their business needs and what services they want from science parks and incubators. Fourth, governments should devise policy to support services that venture businesses want, rather than provide what government thinks is necessary for venture businesses.

This research has several limitations. First, despite the high response rate of $97.5 \%$, restricting the sample frame to the Daejeon metropolitan area limits the applicability of research results. Second, although success factors were derived from a comprehensive literature study, there may be missing factors. Third, entrepreneurs' responses on influences and contributions of success factors are based on perception. So there may be a bias on the part of entrepreneurs - they think they did it all. The fourth limitation concerns the dependent 
variable as to what variables should be operationalized to measure success of venture businesses. This limitation prevents us from exploring cause-and-effect relationship between factors and success.

There are several directions in which this research might be extended. Replicate this research with a larger population including a variety of organization types. Comprehensively examine more influencing (contributing) factors to accurately assess the critical factors for business venture. Include a third-party observer/expert in evaluating the influence and contribution of success factors. Develop reliable and valid measures of the dependent variable in order to devise and empirically test measures of venture success.

\section{References}

[1] T.K. Sung, D.V. Gibson, Knowledge and technology transfer: key factors and levels, Proceedings of 4th International Conference on Technology Policy and Innovation (2000) 4.4.1-4.4.9.

[2] L. Grayson, Science Parks: An Experiment in High-Technology Transfer, British Library, London, 1993.

[3] V.K. Jolly, Commercialization New Technologies, Harvard Business School Press, Boston, MA, 1997.

[4] D. Massey, P. Quintas, D. Wield, High-Tech Fantasies, Routledge, New York, NY, 1992.

[5] H.R. Feeser, Incubators, entrepreneurs, strategy and performance: a comparison of high and low growth high tech firms, PhD dissertation, Purdue University, 1987.

[6] K. Larsen, M. Rogers, Silicon Valley, the rise and falling off of entrepreneurial fever, in: R.W. Smilor, G. Kozmetsky, D.V. Gibson (Eds.), Creating the Technopolis: Linking Technology Commercialization and Economic Development, Ballinger, Massachusetts, 1988, pp. 99-115.

[7] D. Fache, Culture and Entrepreneurial Success: Innovation in Science Park, The Technopolis Phenomenon, Rowman \& Littlefield, Langham, MD, 1992, pp. 193-196.

[8] L.J. Gibson, Science cities or technopolis, science parks and technology parks: alternative models for university participation, Proceedings of the Development Strategies for Science Town (1992) 25-47.

[9] S. Hong, The Know-How of Venture Business, Hanmoonsa, Seoul, 1998.

[10] K. Kim, W. Oh, Success and vitalization strategy for Kyonggi province venture businesses, Development Strategies for Venture Businesses in Kyonggi Province (1997) 111-125.

[11] K. Suh, Study on Facilitating Small and Medium-Size Venture Firms, KOSBI (Korea Small Business Institute), Seoul, 1997.

[12] H. Yang, H. Chu, Y. Cho, Current Status of Venture Firms and Nurturing Strategies, KIET, Seoul, 1997.

[13] L. Bruce, Entrepreneurship: Creating and Managing New Venture, Pergamon, New York, 1989.

[14] A. Cooper, Strategic management: new venture and small business, Long Range Planning 14 (5) (1981) $39-51$.

[15] M. Green, Venture Capital—International Comparisons, Routledge, London, 1991.

[16] J. Lee, Development policy for venture firms, Development Strategies for Venture Businesses in Kyonggi Province (1997) 126-140.

[17] Korea Institute of Economy and Technology (KIET), Venture Capital Expansion Programs, KIET, Seoul, 1998.

[18] National Venture Capital Association (NCVA), National Venture Capital Association 1996 Annual Report, Venture One, San Francisco, CA, 1996.

[19] P. Gompers, Grandstanding in the venture capital industry, Journal of Financial Economics 42 (2) (1996) $133-156$.

[20] J.W. Lee, Venture Business, Maeil Economic Newspaper, Seoul, 1997.

[21] T.K. Sung, C.M. Hyon, Government policy on technopolis development in Korea, Proceedings of the 31st Hawaii International Conference on System Sciences (1998) 252-261. 
[22] Institute of Industrial Technology Policy (ITEP), Theory and Practices of Technoparks in Korea, ITEP, Seoul, Korea, 1998.

[23] R.W. Smilor, D.V. Gibson, The Practical Commercialization of Superconductivity, University of Texas at Austin, Austin, TX, 1989.

[24] D.V. Gibson, T.K. Sung, Technopolis: cross-institutional alliances, International Business Review 18 (1995) 199-217.

[25] M.P. Rice, J.B. Matthews, Growing New Ventures, Creating New Jobs: Principles and Practices of Successful Business Incubation, Quorum Books, New York, 1995.

[26] NBIA (National Business Incubation Association), www.nbia.com, 2001.

[27] P. Bearse, The Evaluation of Business Incubation Projects: A Comprehensive Manual, National Business Incubation, Athens, OH, 1994.

[28] C. Campbell, Change Agents in the New Economy: Business Incubators and Economic Development, National Business Incubation, Athens, OH, 1992.

[29] G. Kozmetsky, D.V. Gibson, L. Kilcrease, NASA (Field Center Based) Technology Commercialization Centers, Report, IC ${ }^{2}$ Institute, Austin, TX, 1993.

[30] IC $^{2}$ Institute, www.ic2.org, 2001.

[31] R. Meeder, Forging the Incubator: How to Design and Implement a Feasibility Study for a Business Incubation Program, National Business Incubation, Athens, OH, 1993.

[32] W.D. Bygrave, J.A. Timmons, Venture Capital at the Cross-Roads, Harvard Business School Press, Boston, MA, 1992.

[33] A. Cooper, Entrepreneurship and paths to business ownership, Strategic Management Journal 7 (1) (1986) $53-68$.

[34] I. Benbasat, A.S. Dexter, An experimental evaluation of graphical and color-enhanced information presentation, Management Science 31 (1) (1985) 1348-1364.

[35] I. Benbasat, A.S. Dexter, An investigation of the effectiveness of color and graphical information presentation under varying time constraints, MIS Quarterly 10 (1) (1986) 59-83.

[36] I. Benbasat, A.S. Dexter, P.S. Masulis, An experimental study of the human/computer interface, Communications of the ACM 24 (11) (1981) 752-762.

[37] P. Ein-dor, E. Segev, A. Steinfeld, Use of management information systems: an experimental study, Proceedings of the 2nd International Conference on Information Systems (1981) 215-228.

[38] S. Rivard, S.L. Huff, User developed applications: evaluation of success from the DP department perspective, MIS Quarterly 8 (1) (1984) 39-50.

[39] W.L. Cron, M.G. Sobol, The relationship between computerization and performance: a strategy for maximizing economic benefits of computerization, Information and Management 6 (1983) 171-181.

[40] C.S. Yap, G. Walsham, A survey of information technology in the U.K. service sector, Information and Management 10 (5) (1986) 267-274.

[41] D.H. Bender, Financial impact of information processing, Journal of MIS 3 (2) (1986) 22-32.

[42] G.M. Kaspar, P. Cerveny, A laboratory study of user characteristics and decision-making performance in experimental setting, Information and Management 9 (2) (1985) 87-96.

[43] T. Lincoln, Do computer systems really pay-off, Information and Management 11 (1) (1986) 25-34.

[44] J. Miller, B.A. Doyle, Measuring effectiveness of computer based information systems in the financial services sector, MIS Quarterly 11 (1) (1987) 107-124.

[45] J.A. Turner, Firm size, performance, and computer use, Proceedings of the Third International Conference on Information Systems (1982) 109-120.

[46] M.A. Vasarhelyi, Information processing in a simulated stock market environment, Proceedings of the 2nd International Conference on Information Systems (1981) 267-274.

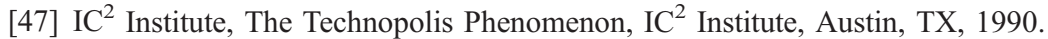

[48] J.B. Sedaitis, Commercializing High Technology, Rowman \& Littlefield, New York, 1997.

[49] R.W. Smilor, G. Kozmetsky, D.V. Gibson, Creating the Technopolis: Linking Technology Commercialization and Economic Development, Ballinger, Massachusetts, 1988. 
[50] R.W. Smilor, D.V. Gibson, G. Kozmetsky, Creating the technopolis: high-technology development in Austin, Texas, Journal of Business Venturing 4 (1988) 49-67.

[51] H.H. Stevenson, D.H. Gumpert, The heart of entrepreneurship, Harvard Business Review 63 (1985) 85-94.

[52] D.V. Gibson, R.W. Smilor, Key variables in technology transfer: a field-study based empirical analysis, Journal of Engineering and Technology Management 8 (1991) 287-312.

[53] C. Hartman, Main Street, INC, Boston, Massachusetts, 1986.

[54] J.K. Galbraith, The New Industrial State, 4th ed., Houghton Mifflin, Boston, MA, 1985.

[55] B.S. Kang, P.W. Kim, Nurturing venture business in Taedok science park, Proceedings of the International Symposium on the Technopolis and Regional Economic Development Strategies (1997) 297-329.

[56] B.S. Kang, Relationship of public-private partnership activities on the small business incubator in Michigan to small business success, PhD dissertation, Michigan State University, 1991.

[57] B.S. Kang, Technology commercialization and business promotion in science park: case study of Taedok science town, Regional Study 13 (2, No. 2) (1997) 22-37.

[58] I.W. Kim, Study on development of high technology technopark through regional technology innovation, Hankook Jebang Jachi Hakbo 10 (1) (1998) 295-312.

[59] S.O. Park, Localization of high technology in Korea and global network, National Planning 13 (1) (1998) $27-42$. 